\title{
From Culex Exposure to West Nile Virus Infection: Screening of Specific Biomarkers
}

\author{
Mahfoud Bakli $^{*}$, Christophe Fraisier ${ }^{1}$, Lionel Almeras ${ }^{1,2}$ \\ ${ }^{1}$ Research Unit on Infectious and Emerging Tropical Diseases, Aix-Marseille University, Marseille, France \\ ${ }^{2}$ Armed Forces Biomedical Research Institute, Marseille, France \\ Email: "mabak83@yahoo.fr, christophe.fraisier@gmail.com, almeras.lionel@gmail.com
}

Received 11 May 2014; revised 11 June 2014; accepted 5 July 2014

Copyright (C) 2014 by authors and Scientific Research Publishing Inc.

This work is licensed under the Creative Commons Attribution International License (CC BY).

http://creativecommons.org/licenses/by/4.0/

(c) (i) Open Access

\begin{abstract}
West Nile virus (WNV) is a mosquito-borne flavivirus contributing yearly, to birds, horses and human morbidity and mortality throughout the world. WNV is transmitted mainly by mosquitoes, predominantly by Culex species, to avian hosts and other vertebrates. Since the mid-1990s, WNV outbreaks and severe human cases (i.e., West Nile neuroinvasive disease) have increased throughout the North hemisphere. The absence of human vaccine and effective therapy needs to understand the pathogenesis of $\mathrm{WN}$ severe disease as well as factors participating in WNV transmission and mosquito exposure. The exploration of the host/vector interaction at the individual level using host antibody response against mosquito salivary proteins has open news research opportunities aiming to increase the impact of surveillance and $W N V$ vector control strategies. This review describes Culex saliva specific biomarkers as a helpful tool to estimate exposure to vector bites and risk for WNV infection, summarizes recent advances regarding WNV vector control strategies and highlights potential specific biomarkers of WN disease severity.
\end{abstract}

\section{Keywords}

West Nile Virus, Culex, Biomarker, Salivary Protein, Antibody Response, Vector Control

\footnotetext{
${ }^{*}$ Corresponding author.
} 


\section{Introduction}

West Nile Virus (WNV) is a positive-stranded RNA virus belonging to the Flaviviridae family (genus Flavivirus), which is transmitted by mosquitoes mainly from the Culex genus [1]. WNV is maintained in an enzootic cycle; birds are the primary natural vertebrate reservoir host for the virus or viral-amplifying hosts [2] [3] (Figure 1). Equines and humans are considered incidental hosts because they did not develop sufficient level of viremia (i.e., concentration of virus in the blood) to infect mosquitoes [4].

Approximately $80 \%$ of WNV infections in humans are asymptomatic, whereas the remainder may manifest West Nile Fever Syndrome (WNF) characterized by sudden fever. Symptoms in 1\% of infected individuals can range from WNF to neurological complications, including meningoencephalitis, and acute-flaccid paralysis usually grouped together under the term West Nile neuroinvasive disease (WNND) [5]. Since its first isolation in 1937, from patient suffering from a mild febrile illness in Omogo in the West Nile province of Uganda, WNV has spread throughout the world and is considered as the most widely distributed of the encephalitic flaviviruses [6]. The virus covers tropical parts of Africa, Middle East, Central Asia, Europe, Australia, and America [7].

Since the mid-1990s, the frequency of WNV outbreaks and clinical severe human cases presenting WNND has increased [8]. Indeed, WNV-outbreaks have become more frequent in Southern European regions [9], such as Italy (200 WNND with 17\% fatality rate) [10], Balkans countries and Greece (197 WNND, of whom 33 (17\%) died) [11]. In 1999, WNV was surprisingly detected during an outbreak of meningo-encephalitis in New York City [12]. Since that time, WNV has spread the north into Canada, and south into Caribbean islands and Central and south America [13] [14]; subsequently, it was considered endemic throughout the Americas [15]. Between 1999 and 2010, nearly 1.8 million people from North America were infected, with more than 15,000 reported cases of severe encephalitis and meningitis, and more than 1500 deaths [16]. The emergence and spread of WNV pose significant public health problem throughout the world, thus, there is a need to develop intervention strategies [17]. To date, four licensed vaccines are available for equines which are effective in preventing morbidity and mortality in horses in the USA and Canada [18]. However, until now, there is no human approved licensed-vaccine or specific treatments [18]. Due to the absence of an effective human vaccine or antiviral drugs, mosquito control measures and personal protection against mosquito bites are crucial to reduce risk of WNV disease transmission [19]. The objective of controlling mosquito populations is to reduce the potential for WNV disease transmission and vector biting nuisances [20].

A critical event in WNV transmission is mosquito bite. Female mosquitoes require hematophagy (blood-

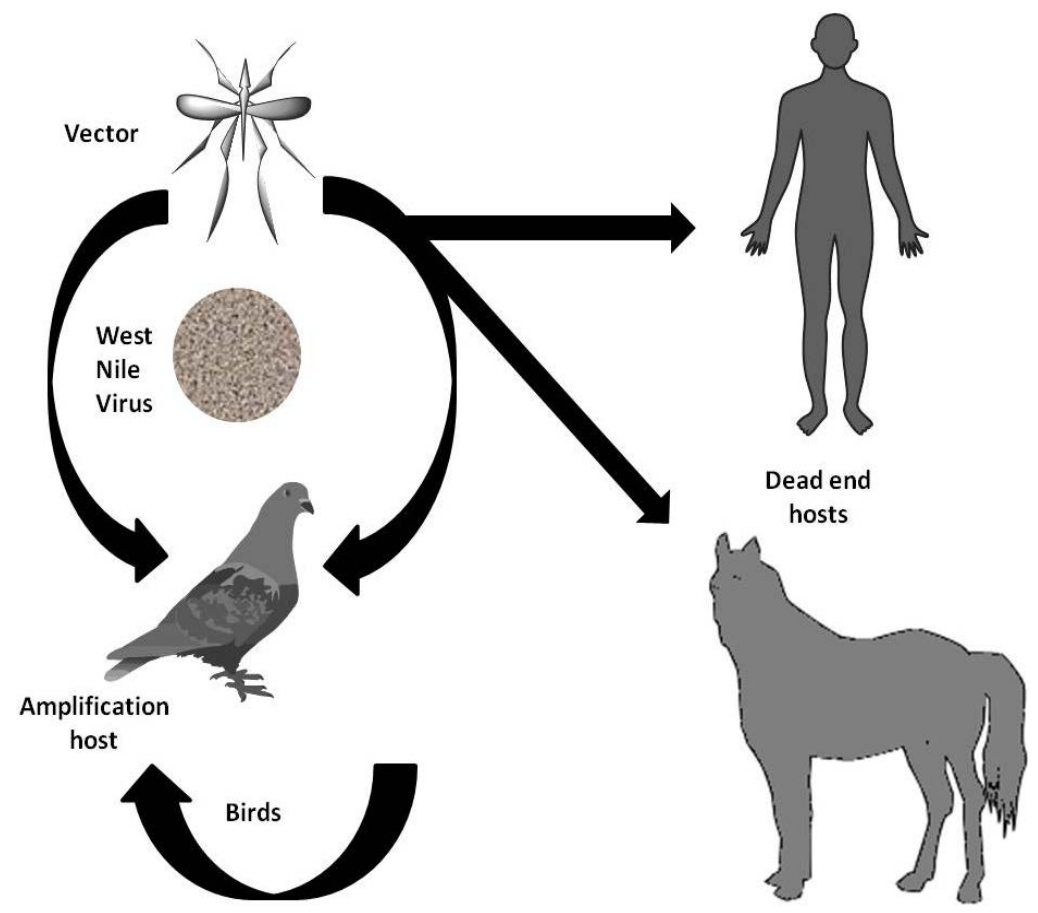

Figure 1. WNV transmission cycle. 
meal) for nutrition, egg development, and survival. During blood-meal, mosquito saliva proteins are injected into the host skin. The saliva contains a number of pharmacologically active proteins, which have effects on the haemostatic responses of the host and modulate both cellular immunity and the production of specific antibodies [21]. There is evidence that mosquito salivary proteins contribute to both susceptibility to WNV infection and disease severity [22]. Moreover, recently a protective role of mosquito salivary gland extract against WNV infection was demonstrated in mice [23]. This result suggests that development of a mosquito salivary protein vaccine might be a strategy to WNV control. It also suggests that the mosquito salivary proteins have an active role in the WNV transmission. Hence, there is a need to identify these proteins involved in the transmission and which their inhibition could have a positive role in decreasing virus transmission or protection against WNV infections (i.e., potential vaccine candidates).

Estimation of individual exposure to hematophagous arthropod vector bites has been established by several studies using antibodies against saliva protein extracts from mosquitoes, ticks, sand flies and Glossina [24]-[29]. Moreover, mosquito salivary gland extracts have been demonstrated to induce specific IgG antibody response in individuals exposed to distinct densities of mosquitoes [30]. This suggests that salivary proteins can potentially be used as specific biomarkers to evaluate individual exposure to mosquito bites [30] [31].

Recent progress regarding WNV diagnosis using serological and molecular tools has been performed [32]. However, currently, human effective antiviral therapy and vaccines are not available [18]. In addition, initial symptoms of WNF are not specific and surviving patients with WNND have a poor prognosis [33]. Therefore, a better understanding of the WNV pathogenesis of severe disease and the prediction of clinical evolution from recovery to neurological symptoms are a major concern. Indeed, the identification of early WNV infection biomarkers and therapeutic targets become urgency in order to diagnose and to distinguish WNF from WNND clinical evolution but also to develop novel and specific therapeutic strategies to prevent brain disorders, sequel or death.

This review highlights the current advances in the use of mosquito saliva specific biomarkers as a helpful tool to estimate exposure to vector bites and risk for WNV infection. We present and summarize also recent advances related to WNV vector control strategies as well as potential specific biomarkers of WN disease severity.

\section{Culex Vectors of WNV and Variability in Vector Competence}

WNV have been detected in at least 75 mosquito species from more than 10 genera worldwide [34]. Culex genus is considered as the most important vector of $\mathrm{WNV}$, although these species vary in their vector competence (Hayes et al., 2005a). These Culex species could serve as efficient enzootic or amplifying vectors for WNV [35]. Among them, mosquitoes of the Culex (Cx.) pipiens complex are major vectors of WNV and other arbovirus diseases including St Louis encephalitis [36], Rift Valley fever [37], Japanese Encephalitis Viruses [38] and Western Equine Encephalitis [39] can be transmitted by these mosquitoes. The Culex pipiens complex includes five species: $C x$. pipiens pipiens (with 2 forms pipiens and molestus), $C x$. pipiens pallens, $C x$. quinquefasciatus, $C x$. australicus, and $C x$. globocoxitus [40]. The most efficient vectors of WNV in the United States are $C x$ quinquefasciatus, $C x$ pipiens, $C x$ restuans, $C x$ salinarius, and $C x$ tarsalis [41]. Less competent vectors were described such as $C x$ nigripalpus, Aedes albopictus, Aedes vexans, and Ochlerotatus triseriatus [41]. Interestingly, $C x$ tarsalis and $C x$. quinquefasciatus seem to be associated with a higher potential risk of human neuroinvasive disease [42].

\section{Surveillance and Control of WNV Vectors}

The surveillance efforts aim to early detect the pathogen circulation in a region and focus on mosquitoes pool surveillance, dead birds count, and analysis of sentinel animals.

Mosquito pool surveillance consisting in the sampling of WNV-infected mosquito pools was reported as the most accurate indicator of possible human cases of WNV infection than monitoring dead and infected wild birds [43]. However, this method cannot be used alone to predict an outbreak and need to be completed with other approaches such as avian surveillance (e.g., bird death as an early warning for WNV human risk) [44]. Culex mosquitoes feed predominantly during the hours from dusk to dawn. Thus, spending a lot of time outdoors overnight or bad screens on windows and doors in this time, present likely a higher risk of exposure to mosquito bites and in areas of WNV circulation their risk to be infected is raised (Campbell et al., 2002). However, public education and instructions on the use of anti-vectorial measures to avoid mosquito exposure remain the primary means of prevention in WNV endemic areas [45]. Thus, exposure to mosquito bites can be anticipated by covering the body 
with long sleeves, long pants, and using of repellents such as N, N-diethyl-methyl-toluamide (DEET).

Another surveillance system was developed from 1999 to 2004 in the Netherlands, which is the syndromic surveillance for early detection of WNV epidemics. This program consisted in analyzing cases presenting neurologic diseases in humans (based on records of unexplained meningitis or encephalitis) and horses. However, this program did not reveal an endemic WNV infection in either humans or horses in the Netherlands [46]. The conclusion from these surveillance and vector control studies is that WNV transmission is hardly predictable and difficult to control. Therefore, timely WNV surveillance (seasonable monitoring pathogen activity in animals and people) on a national scale is required [47].

During the initial human epidemic in New York City in 1999, a striking feature was the high number of avian deaths, particularly in American crows [48]. The occurrence of sudden deaths in birds could represent a sentinel event of WNV spread that can be used as an indicator of WNV density in areas at risk of transmission and can act as a predictive event of human cases [49] and WNV-induced equine mortality [50]. Unfortunately, this passive surveillance becomes less effective due to the decreasing number of voluntary reporting of dead birds [51].

Sentinel animals are groups of animals sampled for WNV and used to detect and measure the spatial and temporal distributions of specific arboviruses. Among sentinel animals studies, serological surveys of wild birds, and horses, containing antibodies that react against WNV antigens, may serve as an early predicting system for WNV outbreaks in humans [52]. During 2004-2010, serological surveys have been conducted to assess circulation of WNV in Portugal, resulting to point horses as good sentinels for WNV infection surveillance compared to birds [53].

In order to reduce mosquito populations, a combination of approaches is often used [44], consisting in mosquito source reduction which is evaluated by mosquito population monitoring. This can be achieved by different means. Recently, it was suggested to use gravid traps, which predominantly attract blood fed females of Culex pipiens complex (thereby aiding in WNV surveillance) and subsequently might be ideal for sampling $C x$. Pipiens populations compared to mass-trapping strategies that use mosquito traps with a combination of attractants (heat, $\mathrm{CO}_{2}$, octenol, light). Because gravid traps predominantly attract previously blood fed female mosquitoes, this method is logistically easier and cheaper to set up [54] [55] Other techniques have been tested like the use of floating layers of polystyrene beads. These beads form a barrier over the surface of the water, leading to a mosquito larvae and pupae suffocation and inhibiting egg laying [56].

Another strategy is the use of chemical treatments. To this end, Culex breeding sites must be identified, mapped, and monitored. Subsequently, these sites should be sprayed with chemical growth regulators larvicide such as methoprene to prevent development of the larvae. Chemical insecticides may be also used in outdoor spraying, impregnated (insecticide-treated) nets (ITNs) or indoor residual spraying (IRS) [57]. Nevertheless, these chemical treatments are expensive and have potential toxic effect on both public health and environment. Furthermore, the development of mosquito resistance against insecticide reduces, in turn, effectiveness of these interventions [58]. In this context, studies have monitored insecticide resistance in Culex pipiens complex populations to ensure the sustainability of vector control programs from Lebanon, France and USA [59]-[61] or more particularly to identify salivary proteins altered in insecticide-resistant $C x$. quinquefasciatus strain [62]. Among these proteins, endoplasmins, triosephosphate isomerases and heat shock proteins (HSP), which are involved in protein folding, glycolysis and stress response respectively, were significantly over-expressed in the salivary glands of insecticide-resistant

$C x$. quinquefasciatus strain. Conversely, the D7 long form salivary protein which is involved in blood feeding success, was found to be underexpressed in the resistant strain compared to the susceptible strain [62]. Because of the increased resistance of mosquito populations to conventional control agents (i.e., pyrethroids and permethrin), biopesticides have been developed [44]. Mosquito biolarvicides based on toxins expressed in recombinant bacteria strains, Bacillus thruingiensis israelensis and Bacillus sphaericus have significantly improved larvicidal efficiency against Culex species [63].

The reduction of mosquito population could also be obtained by infection of mosquitoes with viruses such as Cx. nigripalpus nucleopolyhedrovirus (CuniNPV), a highly pathogenic baculovirus to Culex spp, ([64], or bacteria such as the intracellular bacteria Wolbachia which could be a possible means for pathogen blocking, life shortening or cytoplasmic incompatibility (reproductive modifications leading to poor or no survival of the mosquito offspring) [65]. Successful Wolbachia-based strategies have been used in Aedes populations to control Dengue transmission [66] [67]. Moreover, recent studies have shown that Wolbachia endosymbionts could reduce the ability of WNV to replicate in Drosophila melanogaster and $C x$. quinquefasciatus, and hence decrease 
WNV transmission by inducing resistance to virus [68]. Therefore, among alternative vector control strategies, using biological control agent can increase resistance to arbovirus infection.

Significant recent progress has been made in developing alternative vector control strategies such as genetic modification of wild mosquito populations. Genetic control strategies include Sterile Insect Technique (SIT), Release of Insects with a Dominant Lethal (RIDL), RNAinterference, Homing Endonuclease Genes (HEG). These methods which present numerous advantages but also some limitations have been recently reviewed by Mc Graw and O’Neill [65].

A summary of the different vector control strategies used to control WNV transmission is presented in Table 1 underlining their advantages and disadvantages.

However, evaluation of the efficiency of vector control interventions is a crucial step to determine whether

Table1. Effectiveness of mosquito vector control strategies.

\begin{tabular}{|c|c|c|c|c|}
\hline Class of intervention & Methods & Advantages & Disadvantages & Reference \\
\hline \multirow{3}{*}{$\begin{array}{l}\text { Physical or Environ- } \\
\text { mental Control Meas- } \\
\text { ures }\end{array}$} & $\begin{array}{l}* \text { Reduction of } \\
\text { human/mosquito contact } \\
\text { based on community } \\
\text { participation following } \\
\text { educational efforts }\end{array}$ & $\begin{array}{c}\text { Encourage community to participate } \\
\text { in the planning of surveillance, } \\
\text { evaluation, and management } \\
\text { programmes, reducing sources of } \\
\text { standing water }\end{array}$ & & {$[44]$} \\
\hline & $\begin{array}{l}\text { * breeding site removal } \\
\text { (Source Reduction) }\end{array}$ & $\begin{array}{c}\text { Reducing aquatic habitats for } \\
\text { larval development }\end{array}$ & $\begin{array}{l}\text { The vast number of breeding sites } \\
\text { making the task difficult to achieve }\end{array}$ & {$[20]$} \\
\hline & * Sampling and collection & $\begin{array}{c}\text { Selection of appropriate sampling } \\
\text { methods depends on the surveillance } \\
\text { objecives }\end{array}$ & $\begin{array}{l}\text { It takes time, extensive } \\
\text { effort required }\end{array}$ & [20] \\
\hline Chemical Treatment & * Insecticides & $\begin{array}{l}\text { The most important component in } \\
\text { the vector-control effort }\end{array}$ & $\begin{array}{l}\text { Development of resistance to } \\
\text { pyrethroids, prohibitively } \\
\text { expensive, unsustainable, and } \\
\text { environmentally undesirable, toxic } \\
\text { for public health }\end{array}$ & {$[145][146]$} \\
\hline \multirow{2}{*}{ Biological Control } & $\begin{array}{c}* \text { Establishment of } \\
\text { Wolbachia in mosquito } \\
\text { populations }\end{array}$ & $\begin{array}{l}\text { Powerful mechanism to invade } \\
\text { natural populations through } \\
\text { cytoplasmic incompatibility }\end{array}$ & $\begin{array}{l}\text { Uninfected females are therefore at } \\
\text { a disadvantage, fitness disadvantage }\end{array}$ & {$[66]$} \\
\hline & *Recombinant bacteria & Alternative of insecticides use & $\begin{array}{l}\text { Reduced effectiveness, expense of } \\
\text { raising the organisms, difficulty in } \\
\text { their application }\end{array}$ & {$[63][147]$} \\
\hline \multirow{4}{*}{$\begin{array}{l}\text { Genetic Control } \\
\text { Strategies }\end{array}$} & $\begin{array}{l}\text { * Sterile Insect Technique } \\
\text { (SIT) }\end{array}$ & $\begin{array}{l}\text { Temporary persistence in the } \\
\text { environment }\end{array}$ & $\begin{array}{l}\text { Strain instability, negative effects of } \\
\text { sterilization by irradiation, difficulties } \\
\text { in sex-separation procedures, the } \\
\text { cost of the control program }\end{array}$ & {$[148]$} \\
\hline & $\begin{array}{l}\neq \text { Release of Insects with a } \\
\text { Dominant Lethal (RIDL) }\end{array}$ & $\begin{array}{l}\text { Short-lived presence of the } \\
\text { genetically modified organism in the } \\
\text { population, focus on the release of } \\
\text { males that will not increase nuisance } \\
\text { biting, temporary persistence in the } \\
\text { environment }\end{array}$ & $\begin{array}{l}\text { More expensive than chemical } \\
\text { methods, political resistance to } \\
\text { releasing large numbers of } \\
\text { transgenic mosquitoes, in } \\
\text { development }\end{array}$ & {$[65][149]$} \\
\hline & * RNA interference & $\begin{array}{l}\text { Improving the natural defense } \\
\text { system of the mosquito }\end{array}$ & $\begin{array}{l}\text { The effectiveness of the transgene } \\
\text { is diminished by genetic changes } \\
\text { occurring outside the targeted } \\
\text { region, Stability and loss of a virus } \\
\text { resistance phenotype over time, in } \\
\text { development }\end{array}$ & $\begin{array}{c}{[65][150]} \\
{[151]}\end{array}$ \\
\hline & $\begin{array}{l}\neq \text { Homing Endonuclease } \\
\text { Genes (HEG) }\end{array}$ & $\begin{array}{l}\text { Viability or fecundity, that are active } \\
\text { in one sex or both }\end{array}$ & $\begin{array}{l}\text { Genes may not be } \\
\text { expressed in the correct tissue, } \\
\text { without long-term persistence, } \\
\text { in development }\end{array}$ & {$[149]$} \\
\hline
\end{tabular}

\footnotetext{
*Applicated to WNV control, $\neq$ Not applicated to WNV control.
} 
anti-vectorial measures are well adapted for optimal control of WNV transmission. Currently, the efficiency of anti-WNV-vectors measures is evaluated either by laboratory bioassays tests [69] [70], by clinical tests that measure the burden of WNV disease (i.e., incidence, neurologic morbidity or mortality in clinical cases) [71] or by entomological methods, such as biting behavior of vectors, trapping strategies and human bait catch using adult volunteers are also proposed to assess vector bite exposure [72]. These laboratory, clinical and entomological methods, despite that they have shown their interest in the evaluation of the protection, transmission and vector density in a given area, present considerable limitations such as time consuming, costly, laborious, dependent on the collector skills and present some ethical considerations [73]. Thus, complementary methods evaluating mosquito bites at the individual level and allowing an estimation of vector control strategies efficiency have been proposed. These methods assess host-vector interactions by the detection and quantification of host serological response against antigenic salivary proteins from hematophagous arthropods which could be used as vector exposure biomarkers [73].

\section{Culex Salivary Proteins: Blood Feeding, Potential Antigenic Biomarkers of Mosquito Bites and Involvement in Pathogen Transmission}

Hematophagous arthropods such as female mosquitoes probe into the host with the proboscis to take blood meals. The saliva of mosquitoes is composed secreted proteins, which affect vascular constriction, blood coagulation, platelet aggregation, inflammation and have an antimicrobial function [74]. During blood feeding, the pathogen could be transmitted into the host via saliva from infected mosquitoes [75].

The host homeostatic and immune system act readily to counteract the tissue injury and assault at the bite site. Pharmacologically active molecules of blood feeding arthropods saliva must not only counteract host homeostasis but also modulate the adaptive host immune response and inflammation [74] [76] [77]. Mosquito saliva contains cytokine modulators, neutrophil chemotactic factor, inflammation inhibitors, inhibitors of the plasma contact system activation and $\mathrm{T}$ and $\mathrm{B}$ lymphocytes activation [78].

The injection of salivary proteins during the mosquito bite can induce a specific host immune response. The recent demonstration of the detection of vector-host contact at the individual level using this host antibody response against vector salivary proteins, as immunological markers of exposure to mosquito bites, have open news research opportunities [79] [80].

These immunological tools of mosquito immunogenic salivary proteins markers aiming the assessment of human or animal antibodies responses to vector exposure could provide direct information about incidence and prevalence of WNV vector and gives predicting tools of WNV human risk transmission in endemic areas.

For Culex mosquitoes, a specific human antibody response to $C x$. quinquefasciatus saliva was found to be correlated with vector prevalence in a Wurchereria bancrofti endemic region [81]. Several studies evaluating immune response against saliva of Culex mosquito as potential biomarkers to evaluate vector exposure have been carried out using salivary gland extracts (SGE) from $C x$. quinquefasciatus [82]-[84], $C x$. tarsalis [22], $C x$. pipiens [30], and $C x$. pallens [85]. Indeed, concerning allergic reactions to mosquito bites, lymphoproliferative responses to different mosquito SGE have been demonstrated in patients with hypersensitivity to mosquito bites [86]. In addition, the major allergens profile patterns of SGE which induce specific IgE responses in the pooled sera of subjects allergic to mosquito bites were identified with some consistent results [82] [84]. Moreover, detection of anti-saliva IgG antibody immune responses against salivary antigens have been useful tool to assess individual exposure to Culex mosquito bites according to seasonal mosquito densities in Southeast France [30]. However the use of SGE presents technical limits such as the number of female mosquitoes necessary for salivary gland dissection, the collection of salivary gland which is laborious and time-consuming, the problem to standardize salivary contents, and the mode of SGE conservation to avoid protein degradation [30] [87]. Although, it has been reported that among mosquitoes, SGE contain specific salivary proteins allowing vector distinction at the species level [88], several salivary proteins are conserved among genera or species, which makes these SGE not suitable for mosquito exposure assessment among both genus and species. Taken together these data, the identification specific immunogenic salivary proteins from Culex mosquitoes, as potential candidates for evaluating the real human-vector contact is need. The selected proteins could be produced in recombinant form and further tested in immunological assays to accurately assess individual exposure to Culex mosquito bites [30]. This candidate selection strategy has been reported to define species-specific [89] or genus-specific [90]-[97] exposure biomarkers to Anopheles bites. 
Orthologous salivary protein sequences are shared among different species and genera from Culicidae. These sequences can be selected and identified to be specific antigenic protein candidates to develop anti-saliva based immunological tools to assess individual exposure to different mosquito vectors.

Genomic, sialotransciptomic or proteomic data of Culex mosquitoes are required in order to select potential specific immunological candidates. However, only few mosquito genome sequences are available. Until now, only $C x$. quinquefasciatus genome sequencing [100] and $C x$. tarsalis and $C x$. quinquefasciatus sialotranscriptome have been described [99] [101] Thus, the limited number of sequenced mosquitoes from the Culex genus available makes difficult the determination species-specific markers. Sialotranscriptome studies of female Culicine (Ae. aegypti, Ae. albopictus and Cx. quinquefasciatus) revealed about 150 different secreted proteins associated with the salivary function grouped, for some of them, into functional families such as D7 salivary proteins, 5' nucleotidase family, and 29/30-kDa protein family. These proteins are salivary specific proteins (i.e., protein families expressed uniquely in salivary glands) [74] [101] [102]. Among these proteins, Reagan et al. identified the $C x$. tarsalis D7 salivary protein (have significant similarity with long form D7clu12 salivary protein fro, $C x$. quinquefasciatus, gi16225986) belonging to D7 protein family, which is one of the most abundant and immunogenic proteins common to all female mosquitoes [103]. In particular, salivary transcriptome analysis revealed a large protein family unique to the Culex genus, named the $16.7 \mathrm{kD}$ family [104], including 28 genes, with unknown protein functions for the majority. Most of these genes are uniexonic, suggesting an expansion by retrotransposition [98] In addition to the $16.7 \mathrm{kDa}$ family, Calvo et al. listed the characteristics of other salivary glands transcripts families found uniquely in Culex genus, such as GQP repeat family, $9.7 \mathrm{kDa}$ family, $4.2 \mathrm{kDa}$ family, HHI repeat family, Cysteine and Tryptophan rich protein family (CWRP), and $7.8 \mathrm{kDa}$ family [110]. These data indicated that these genus-specific salivary proteins seem to be interesting potential candidates for the evaluation of host serological responses against Culex genus bites. In addition, among these proteins, their orthologs belonging to D7 family have already been tested in other species and showed that it could be antigenic [82] [84] [103], making them interesting Culex genus-specific biomarkers candidates of mosquito exposure.

Previous studies reported that mosquito saliva proteins induce infection compared to syringe injection of pathogen without saliva proteins [105]-[108]. Several studies have shown the protective role of saliva in the transmission of the parasite or arborvirus. Indeed, a prior exposure of mice to uninfected mosquito bites reduced parasite or arbovirus transmission [109] [110]. These data suggest that mosquito saliva participates in pathogen transmission and confer protection against infection with pathogen.

Potentialisation of mosquito saliva in the WNV transmission has been demonstrated in $C x$. tarsalis [110] and Ae. aegypti-exposed mice [111] [112] and in Cx. pipiens-exposed chicken [113]. All of these data have demonstrated that in a mouse model, mosquito feeding leading to the injection of saliva proteins potentiates WNV infection including enhancement of disease progression and mortality, increasing viremia and accelerating neuroinvasion [111] [114] [115]. Moreover, mice immunized with the D7 recombinant salivary proteins from $C x$. tarsalis mosquitoes prior exposure to WNV-infected mosquitoes bites have been shown to enhances WNV infection [103]. In contrast, mortality caused by WNV was significantly reduced in the $C x$. tarsalis SGE-immunized mice [23]. Collectively, mosquito saliva could have a protective role (potential vaccine) limiting WNV infection. Therefore, identification of salivary proteins with potentiating infection role or production of specific antibodies against these proteins aiming to investigate the protective effect could open new strategies for protecting against WNV transmission (vaccination). Nonetheless, various parameters need to be further investigated, such as differences in mosquito species, mouse strains, and method of exposure to mosquito bite and dose of mosquito salivary proteins [116].

The determination of salivary proteins from Culex mosquitoes involvement in WNV infection could be important in understanding virus transmission and pathogenesis. They could be used as possible new therapeutic agents [117] and potential targets for vaccine strategies against pathogen transmission [78], thereby preventing immune-modulation caused by mosquito saliva or promoting the induction of host immune response against the pathogen [118]. Although D7 recombinant protein vaccine induces host WNV-specific immune response, it enhanced the mortality in the mouse model of WNV infection via mosquito bite [22]. This study illustrates the complexity of the immune response to salivary proteins and requires further complementary studies [22]. However some of these mosquito salivary proteins have the advantage to be conserved in a mosquito genus, although the mosquito vectors can transmit different strains of different arboviruses. Thus, the use of these proteins in vaccine strategies is better than viral surface proteins, because of, viral proteins have antigenic domains which are more variable [119], making them difficult in developing a global vaccine against WNV and other arbovirus 
infections.

\section{WNV Infection Biomarkers of Neuroinvasive Disease}

The progression to WN severe infection may induce acute flaccid paralysis after meningitis or encephalitis [120]. The severe form of WNV disease has been estimated to occur at a frequency about 1 in 150 infections [17]. Individuals at highest risk of developing WNV-induced encephalitis are the elderly (>70 years) and immuno-compromised individuals [42]. In the elderly, the case-fatality rate could reach $20 \%$ [121]. Thus, as the number of WN severe cases have increased this last decade in the united States and Europe [9], it become urgency to ameliorate early clinical diagnosis, to develop new indicator for disease evolution and to better understand pathophysiological mechanisms for the development of new therapeutic strategies.

\subsection{Diagnosis and Treatment of WNV}

Clinical diagnosis of WNV is based on the detection of antibodies IgM or IgG, viral nucleic acids by RT-PCR (standard and real-time) in the blood or cerebrospinal fluid (CSF), or the isolation of infectious virus in cell cultures [4]. Nevertheless, diagnosis of WNV infection is predominantly serological [122], because of the low sensivity of molecular methods for new emerging WNV strains [18]. However, serologic methods can be problematic because of cross-reactivity among different serotypes of WNV and other flaviviruses [4]. Currently, all these diagnosis tests detect WNV directly (RT-PCR or culture) or indirectly (serological tests). However, there are no laboratory biomarkers associated to WNV disease severity or allowing predicting clinical evolution.

In addition, nowadays, there is no specific curative treatment for $\mathrm{WN}$ disease, only recommended treatment is supportive care [123]. Interferon-alpha (IFN- $\alpha$ ) have been used in treatment of patients with WN encephalitis [124] [125], Ribavirin (antiviral agent) also used in therapy of experimental WN fever [126], and a transfer of immunoglobulins anti-WN (antibody therapy) [127]. Experimental studies evaluating specific therapies for WNV infections have not been completed. However, case report studies suggesting treatment efficacy should be cautiously interpreted, since the clinical course and outcomes with WNND are highly variable [128].

\subsection{Pathophysiological Processes of WNV Infection, Global Analysis Approaches}

Genomic, transcriptomic and proteomic analysis studies have greatly improved our knowledge of the pathophysiological processes following WNV infections [129]-[133]. Genomic study aiming to determine genetic factors predisposing to neurological complications following WNV infection, did not identified Single Nucleotide Polymorphism (SNP) of genes associated with neuroinvasive disease in patients infected with WNV [131].

Among DNA microarray studies, for example, DNA microarray analyses have been used to define transcriptomic profiles of genes involved in host response to WNV in infected mouse embryo fibroblasts [130] and used also to compare gene expressions in mice infected with WNV strains of different neurovirulence [133]. These global transcriptional studies demonstrated differentially expressed of: 1) genes involved in antiviral responses such as interferon-stimulated genes (ISGs), and 2) genes involved in neurovirulence such as expression of central nervous system specific genes.

At the protein level, proteomic profiling permited the identification of proteins whose expression levels were altered due to WNV infection in rat neurons [129] and Vero cells [132]. In addition, recently, proteomic study investigated the pathophysiological processes in severe WNV infection in mice, using kinetic analysis of protein expression profiles in the brain of WNV-infected mice prior and after the onset of clinical symptoms [134]. These proteomic studies in infected host cells revealed several host cellular functions that were altered following WNV infections: apoptotic pathway, cell cycle regulation or cytoskeleton maintenance associated with virus circulation, protein ubiquitination pathway, inflammatory response, and neurological development and neuronal cell death. The proteomic changes were attributed to either proviral or antiviral phenomena and allowed identification of potential biomarkers of clinical course of WNV disease. The potential biological markers associated either to WNV infection or to disease evolution are detailed below.

\subsection{Clinical Evolution Biomarkers}

Clinical evolution biomarkers can aid in the diagnosis as well as prognosis and monitoring of patients with encephalitis [135]. In addition, protein biomarkers are an attractive tool for assessing the severity of brain dam- 
age and outcome in various CNS diseases [136]. Indeed, following axonal and neuronal damage within the CNS, some proteins were released and can be quantified from CSF. The protein biomarkers, S100B, glial fibrillary acidic protein (GFAP) and neurofilament protein (NFL) may reflect neuronal damage, but they are not specific biomarkers of severity of WN disease [137].

Indeed, a measure CSF levels of neuronal (neurofilaments, NfH-SMI35) and glial (glial fibrillary acidic protein, GFAP, S100B) protein biomarkers revealed that these biomarkers were found significatly more elevated in WNV encephalitis patients compared to non-inflammatory controls [137]. However, these biomarkers of WN disease severity (S100B, NfH-SMI35, and GFAP) of CSF were also present in sera from WNF patients [138]-[140].

In order to better understand the pathophysiological processes in severe WNV infection and research early biomarkers of clinical course of WN disease, a recent proteomic study used animal model to this purpose. Potential protein biomarker candidates associated with the severity of WN disease clinical evolution are suggested such as High Mobility Group Box 1 (HMGB1) and Peroxiredoxin (PRDX6) [134]. This study has shown the kinetic modulation (the increased expression of HMGB1 and PRDX6 at the early and late time-points, respectively) of the inflammatory response leading to brain injuries following WNV infection [134]. HMGB1 belongs to danger-associated molecular patterns (DAMPs) which are alarm molecules that alert immune cells to the presence of brain tissue injury. PRDX6 is also shown to be involved in ischemic brain injury [141]. It has been reported the potential of the HMGB1 protein as an auxiliary biomarker for early dengue disease diagnosis [142]. Although, these proteins could be predictive biomarkers of traumatic brain injury, they are not specific to WN disease. Interestingly, comparable kinetic of production of HMGB1 and PRDX have been demonstrated in response to brain ischemic stroke [143]. Thus, the release of these proteins could evaluate the degree of brain injury following WNV infection [134]. Taken together, these proteins could be clinical evolution biomarkers of WN disease, HMGB1 predicts (predictive biomarker) before the onset of clinical signs and PRDX6 reflects of the CNS pathology following WNV infection. Moreover, these biomarkers could be potential targets in therapeutic strategies, because PRDX6 and HMGB1 neutralizing antibodies have been shown to suppress inflammatory cytokine expression in the ischemic brain and to protect the blood-brain barrier from ischemia-induced disruption, respectively [143] [144].

Collectively, these studies have proposed some potential candidates which could be used either to predict risk of severe case or to confirm brain damage. Nevertheless, additional studies are need on large population to comfort the potential of these proteins to predict and/or distinct WNF from WNND.

\section{Conclusions and Prospects}

West Nile Virus disease is an importance for public health, and in the absence of treatment and available human vaccine, the current best way to fight this disease is to prevent vector bites, and use of vector surveillance program. At the individual scale, personal protective measures aim to reduce host exposure during outdoor activities by using mosquito repellents and wearing long sleeved clothes. In the last decade, significant progress has been made in developing vector control strategies fighting WNV transmission. These strategies are in development and could be combined together to fight the expending distribution of WN disease. In addition, the use of host antibody response against vector salivary proteins has repeatedly shown to be a promising method to assess host/vector contact at the qualitative and quantitative levels. The future evaluation of some Culex genus salivary candidtes presented in the present review could be helpful in the development of original tools for the estimation of the host/Culex contact. Interestingly, the recent description of the potentialisation of salivary protein in WNV transmission and inversely their potential protective role in sensitization of hosts underlined the increasing interest of these proteins for vaccinal strategies.

Concerning the pathophysiological processes of WNV neuroinvasive disease, although some analyses of transcriptomic and proteomic profiles in the brain of susceptible animals after infection with WNV were performed, only one of them considered clinical onset evolution. A better description of the mechanisms of WNV infection during the course of clinical symptoms appears indispensable to propose new potential therapeutic target or biomarkers associated to severe forms. Such candidates could be helpful in the prevention of unfavorable clinical evolution, but also in the diagnosis and monitoring of severe neurological cases aiming to reduce mortality and neurological sequelae in humans and the development of new treatments.

The combination of WNV vector exposure biomarkers with WNV infection biomarkers associated to clinical evolution can provide reliable tools to help public health authorities in planning key strategies to reduce the 
burden of WNV transmission and the rate of fatality cases.

\section{Competing Interests}

The authors have declared no conflict of interest.

\section{Author Contribution}

MB and LA conceived the intellectual content of the article. MB and AL collected results presented here and wrote first draft of the manuscript. MB: designed all figures. CF participated in the formation of the final version of manuscript.

\section{References}

[1] Murphy, F.A., Fauquet, C.M., Bishop, D.H.L., Ghabrial, S.A., Jarvis, A.W., Martelli, G.P. and Mayo, M.A. (1995) Virus Taxonomy: Classification and Nomenclature of Virus. Springer, Berlin, $421 \mathrm{p}$.

[2] Baqar, S., Hayes, C.G., Murphy, J.R. and Watts, D.M. (1993) Vertical Transmission of West Nile Virus by Culex and Aedes Species Mosquitoes. The American Journal of Tropical Medicine and Hygiene, 48, 757-762.

[3] Campbell, G.L., Marfin, A.A., Lanciotti, R.S. and Gubler, D.J. (2002) West Nile Virus. The Lancet Infectious Diseases, 2, 519-529. S1473309902003687 [pii]

[4] Kauffman, E.B., Franke, M.A., Wong, S.J. and Kramer, L.D. (2011) Detection of West Nile Virus. Methods in Molecular Biology, 665, 383-413. http://dx.doi.org/10.1007/978-1-60761-817-1_21

[5] Sips, G.J., Wilschut, J. and Smit, J.M. (2012) Neuroinvasive Flavivirus Infections. Reviews in Medical Virology, 22, 69-87. http://dx.doi.org/10.1002/rmv.712

[6] May, F.J., Davis, C.T., Tesh, R.B. and Barrett, A.D. (2011) Phylogeography of West Nile Virus, From the Cradle of Evolution in Africa to Eurasia, Australia, and the Americas. Journal of Virology, 85, 2964-2974. JVI.01963-10 [pii]

[7] Tolle, M.A. (2009) Mosquito-Borne Diseases. Current Problems in Pediatric and Adolescent Health Care, 39, 97-140. S1538-5442(09)00014-5 [pii]

[8] Petersen, L.R. and Marfin, A.A. (2002) West Nile Virus: A Primer for the Clinician. Annals of Internal Medicine, 137, 173-179. 200208060-00009 [pii]

[9] Sambri, V., Capobianchi, M., Charrel, R., Fyodorova, M., Gaibani, P., Gould, E., Niedrig, M., Papa, A., Pierro, A., Rossini, G., Varani, S., Vocale, C. and Landini, M.P. (2013) West Nile Virus in Europe: Emergence, Epidemiology, Diagnosis, Treatment, and Prevention. Clinical Microbiology and Infection, 19, 699-704. http://dx.doi.org/10.1111/1469-0691.12211

[10] Rizzo, C., Salcuni, P., Nicoletti, L., Ciufolini, M.G., Russo, F., Masala, R., Frongia, O., Finarelli, A.C., Gramegna, M., Gallo, L., Pompa, M.G., Rezza, G., Salmaso, S. and Declich, S. (2012) Epidemiological Surveillance of West Nile Neuroinvasive Diseases in Italy, 2008 to 2011. Eurosurveillance, 17.

[11] Danis, K., Papa, A., Theocharopoulos, G., Dougas, G., Athanasiou, M., Detsis, M., Baka, A., Lytras, T., Mellou, K., Bonovas, S. and Panagiotopoulos, T. (2011) Outbreak of West Nile Virus Infection in Greece, 2010. Emerging Infectious Diseases, 17, 1868-1872. http://dx.doi.org/10.3201/eid1710.110525

[12] Lanciotti, R.S., Roehrig, J.T., Deubel, V., Smith, J., Parker, M., Steele, K., Crise, B., Volpe, K.E., Crabtree, M.B., Scherret, J.H., Hall, R.A., MacKenzie, J.S., Cropp, C.B., Panigrahy, B., Ostlund, E., Schmitt, B., Malkinson, M., Banet, C., Weissman, J., Komar, N., Savage, H.M., Stone, W., McNamara, T. and Gubler, D.J. (1999) Origin of the West Nile Virus Responsible for an Outbreak of Encephalitis in the Northeastern United States. Science, 286, 2333-2337. 8110 [pii]

[13] Hayes, E.B., Komar, N., Nasci, R.S., Montgomery, S.P., O’Leary, D.R. and Campbell, G.L. (2005) Epidemiology and Transmission Dynamics of West Nile Virus Disease. Emerging Infectious Diseases, 11, 1167-1173. http://dx.doi.org/10.3201/eid1108.050289a

[14] Kilpatrick, A.M. (2011) Globalization, Land Use, and the Invasion of West Nile Virus. Science, 334, 323-327. 334/6054/323 [pii]

[15] Petersen, L.R. and Hayes, E.B. (2008) West Nile Virus in the Americas. Medical Clinics of North America, 92, 13071322, ix. http://dx.doi.org/10.1016/j.mcna.2008.07.004

[16] Fredericksen, B.L. (2013) The Neuroimmune Response to West Nile Virus. Journal of NeuroVirology, 20, 113-121.

[17] Suthar, M.S., Diamond, M.S. and Gale, Jr., M. (2013) West Nile Virus Infection and Immunity. Nature Reviews Microbiology, 11, 115-128. nrmicro2950 [pii] 
[18] DeFilette, M. (2012) Recent Progress in West Nile Virus Diagnosis and Vaccination. Veterinary Research, 43, 16.

[19] Winters, A.M., Eisen, R.J., Lozano-Fuentes, S., Moore, C.G., Pape, W.J. and Eisen, L. (2008) Predictive Spatial Models for Risk of West Nile Virus Exposure in Eastern and Western Colorado. The American Journal of Tropical Medicine and Hygiene, 79, 581-590. 79/4/581 [pii]

[20] Medlock, J.M., Hansford, K.M., Schaffner, F., Versteirt, V., Hendrickx, G., Zeller, H. and Van, B.W. (2012) A Review of the Invasive Mosquitoes in Europe: Ecology, Public Health Risks, and Control Options. Vector-Borne and Zoonotic Diseases, 12, 435-447. http://dx.doi.org/10.1089/vbz.2011.0814

[21] Billingsley, P.F., Baird, J., Mitchell, J.A. and Drakeley, C. (2006) Immune Interactions between Mosquitoes and Their Hosts. Parasite Immunology, 28, 143-153. PIM805 [pii]

[22] Reagan, K.L., Machain-Williams, C., Wang, T. and Blair, C.D. (2012) Immunization of Mice with Recombinant Mosquito Salivary Protein D7 Enhances Mortality from Subsequent West Nile Virus Infection via Mosquito Bite. PLOS Neglected Tropical Diseases, 6, Article ID: e1935. PNTD-D-12-00770 [pii]

[23] Machain-Williams, C., Reagan, K., Wang, T., Zeidner, N.S. and Blair, C.D. (2013) Immunization with Culex Tarsalis Mosquito Salivary Gland Extract Modulates West Nile Virus Infection and Disease in Mice. Viral Immunology, 26, 8492. http://dx.doi.org/10.1089/vim.2012.0051

[24] Poinsignon, A., Remoue, F., Rossignol, M., Cornelie, S., Courtin, D., Grebaut, P., Garcia, A. and Simondon, F. (2008) Human IgG Antibody Response to Glossina Saliva: An Epidemiologic Marker of Exposure to Glossina Bites. The American Journal of Tropical Medicine and Hygiene, 78, 750-753. 78/5/750 [pii]

[25] Andrade, B.B. and Teixeira, C.R. (2012) Biomarkers for Exposure to Sand Flies Bites as Tools to Aid Control of Leishmaniasis. Frontiers in Immunology, 3, 121. http://dx.doi.org/10.3389/fimmu.2012.00121

[26] Cornelie, S., Remoue, F., Doucoure, S., Ndiaye, T., Sauvage, F.X., Boulanger, D. and Simondon, F. (2007) An Insight into Immunogenic Salivary Proteins of Anopheles gambiae in African Children. Malaria Journal, 6, 75. 1475-2875-6-75 [pii]

[27] Nascimento, R.J., Santana, J.M., Lozzi, S.P., Araujo, C.N. and Teixeira, A.R. (2001) Human IgG1 and IgG4: The Main Antibodies against Triatoma infestans (Hemiptera: Reduviidae) Salivary Gland Proteins. The American Journal of Tropical Medicine and Hygiene, 65, 219-226.

[28] Palosuo, K., Brummer-Korvenkontio, H., Mikkola, J., Sahi, T. and Reunala, T. (1997) Seasonal Increase in Human IgE and IgG4 Antisaliva Antibodies to Aedes Mosquito Bites. International Archives of Allergy and Immunology, 114, 367-372. http://dx.doi.org/10.1159/000237696

[29] Vu, H.V., Pages, F., Boulanger, N., Audebert, S., Parola, P. and Almeras, L. (2013) Immunoproteomic Identification of Antigenic Salivary Biomarkers Detected by Ixodes Ricinus-Exposed Rabbit Sera. Ticks and Tick-Borne Diseases, 4, 459-468. S1877-959X(13)00060-5 [pii]

[30] Fontaine, A. (2011) Relationship between Exposure to Vector Bites and Antibody Responses to Mosquito Salivary Gland Extracts. PLOS One, 6, Article ID: e29107.

[31] Remoue, F., Alix, E., Cornelie, S., Sokhna, C., Cisse, B., Doucoure, S., Mouchet, F., Boulanger, D. and Simondon, F. (2007) IgE and IgG4 Antibody Responses to Aedes Saliva in African Children. Acta Tropica, 104, 108-115.

[32] Sanchini, A., Donoso-Mantke, O., Papa, A., Sambri, V., Teichmann, A. and Niedrig, M. (2013) Second International Diagnostic Accuracy Study for the Serological Detection of West Nile Virus Infection. PLoS Neglected Tropical Diseases, 7, Article ID: e2184.

[33] Gubler, D.J. (2007) The Continuing Spread of West Nile Virus in the Western Hemisphere. Clinical Infectious Diseases, 45, 1039-1046. CID51212 [pii]

[34] Medlock, J.M., Snow, K.R. and Leach, S. (2005) Potential Transmission of West Nile Virus in the British Isles: An Ecological Review of Candidate Mosquito Bridge Vectors. Medical and Veterinary Entomology, 19, 2-21. MVE547 [pii]

[35] Turell, M.J., Dohm, D.J., Sardelis, M.R., Oguinn, M.L., Andreadis, T.G. and Blow, J.A. (2005) An Update on the Potential of North American Mosquitoes (Diptera: Culicidae) to Transmit West Nile Virus. Journal of Medical Entomology, 42, 57-62. http://dx.doi.org/10.1603/0022-2585(2005)042[0057:AUOTPO]2.0.CO;2

[36] Pesko, K. and Mores, C.N. (2009) Effect of Sequential Exposure on Infection and Dissemination Rates for West Nile and St. Louis Encephalitis Viruses in Culex quinquefasciatus. Vector-Borne and Zoonotic Diseases, 9, 281-286. http://dx.doi.org/10.1089/vbz.2007.0281

[37] Turell, M.J., Presley, S.M., Gad, A.M., Cope, S.E., Dohm, D.J., Morrill, J.C. and Arthur, R.R. (1996) Vector Competence of Egyptian Mosquitoes for Rift Valley Fever Virus. American Journal of Tropical Medicine and Hygiene, 54, 136-139.

[38] Weng, M.H., Lien, J.C., Lin, C.C. and Yao, C.W. (2000) Vector Competence of Culex pipiens Molestus (Diptera: Cu- 
licidae) from Taiwan for a Sympatric Strain of Japanese Encephalitis Virus. Journal of Medical Entomology, 37, 780783. http://dx.doi.org/10.1603/0022-2585-37.5.780

[39] Steele, K.E. and Twenhafel, N.A. (2010) REVIEW PAPER: Pathology of Animal Models of Alphavirus Encephalitis. Veterinary Pathology, 47, 790-805. 0300985810372508 [pii]

[40] Farajollahi, A., Fonseca, D.M., Kramer, L.D. and Marm, K.A. (2011) "Bird Biting” Mosquitoes and Human Disease: A Review of the Role of Culex pipiens Complex Mosquitoes in Epidemiology. Infection, Genetics and Evolution, 11, 1577-1585. S1567-1348(11)00292-9 [pii]

[41] Trevejo, R.T. and Eidson, M. (2008) Zoonosis Update: West Nile Virus. Journal of the American Veterinary Medical Association, 232, 1302-1309. http://dx.doi.org/10.2460/javma.232.9.1302

[42] Artsob, H., Gubler, D.J., Enria, D.A., Morales, M.A., Pupo, M., Bunning, M.L. and Dudley, J.P. (2009) West Nile Virus in the New World: Trends in the Spread and Proliferation of West Nile Virus in the Western Hemisphere. Zoonoses and Public Health, 56, 357-369. JVB1207 [pii]

[43] Brownstein, J.S., Holford, T.R. and Fish, D. (2004) Enhancing West Nile Virus Surveillance, United States. Emerging Infectious Diseases, 10, 1129-1133.

[44] Kramer, L.D., Styer, L.M. and Ebel, G.D. (2008) A Global Perspective on the Epidemiology of West Nile Virus. Annual Review of Entomology, 53, 61-81. http://dx.doi.org/10.1146/annurev.ento.53.103106.093258

[45] Mergl, R. (2010) Transmission of West Nile Virus in the Niagara Region among a Population at Risk for Exposure. Dissertation, Faculty of Applied Health Sciences Brock University St Catharines, Ontario.

[46] Rockx, B., van Asten, L., van den Wijngaard, C., Godeke, G.J., Goehring, L., Vennema, H., van der Avoort, H., van Pelt, W. and Koopmans, M. (2006) Syndromic Surveillance in the Netherlands for the Early Detection of West Nile Virus Epidemics. Vector-Borne and Zoonotic Diseases, 6, 161-169. http://dx.doi.org/10.1089/vbz.2006.6.161

[47] Petersen, L.R. and Fischer, M. (2012) Unpredictable and Difficult to Control-The Adolescence of West Nile Virus. New England Journal of Medicine, 367, 1281-1284. http://dx.doi.org/10.1056/NEJMp1210537

[48] Eidson, M., Komar, N., Sorhage, F., Nelson, R., Talbot, T., Mostashari, F. and McLean, R. (2001) Crow Deaths as a Sentinel Surveillance System for West Nile Virus in the Northeastern United States, 1999. Emerging Infectious Diseases, 7, 615-620. http://dx.doi.org/10.3201/eid0704.010402

[49] Guptill, S.C., Julian, K.G., Campbell, G.L., Price, S.D. and Marfin, A.A. (2003) Early-Season Avian Deaths from West Nile Virus as Warnings of Human Infection. Emerging Infectious Diseases, 9, 483-484. http://dx.doi.org/10.3201/eid0904.020421

[50] Roberts, R.S. and Foppa, I.M. (2006) Prediction of Equine Risk of West Nile Virus Infection Based on Dead Bird Surveillance. Vector-Borne and Zoonotic Diseases, 6, 1-6. http://dx.doi.org/10.1089/vbz.2006.6.1

[51] Mostashari, F., Kulldorff, M., Hartman, J.J., Miller, J.R. and Kulasekera, V. (2003) Dead Bird Clusters as an Early Warning System for West Nile Virus Activity. Emerging Infectious Diseases, 9, 641-646. http://dx.doi.org/10.3201/eid0906.020794

[52] Castillo-Olivares, J. and Wood, J. (2004) West Nile Virus Infection of Horses. Veterinary Research, 35, 467-483. V4014 [pii]

[53] Barros, S.C., Ramos, F., Fagulha, T., Duarte, M., Henriques, M., Luis, T. and Fevereiro, M. (2011) Serological Evidence of West Nile Virus Circulation in Portugal. Veterinary Microbiology, 152, 407-410. S0378-1135(11)00277-X [pii]

[54] Kesavaraju, B., Kiyoguchi, D. and Dickson, S. (2011) Efficacy of Gravid Traps in Trapping Culex pipiens. Journal of the American Mosquito Control Association, 27, 320-322. http://dx.doi.org/10.2987/11-6136.1

[55] Kline, D.L. (2006) Traps and Trapping Techniques for Adult Mosquito Control. Journal of the American Mosquito Control Association, 22, 490-496. http://dx.doi.org/10.2987/8756-971X(2006)22[490:TATTFA]2.0.CO;2

[56] Curtis, C. (2005) Insecticide-Treated Nets against Malaria Vectors and Polystyrene Beads against Culex larvae. Trends in Parasitology, 21, 504-507. S1471-4922(05)00252-7 [pii]

[57] Nkya, T.E., Akhouayri, I., Kisinza, W. and David, J.P. (2013) Impact of Environment on Mosquito Response to Pyrethroid Insecticides: Facts, Evidences and Prospects. Insect Biochemistry and Molecular Biology, 43, 407-416. S0965-1748(12)00147-6 [pii]

[58] Briet, O.J., Penny, M.A., Hardy, D., Awolola, T.S., Van, B.W., Corbel, V., Dabire, R.K., Etang, J., Koudou, B.G., Tungu, P.K. and Chitnis, N. (2013) Effects of Pyrethroid Resistance on the Cost Effectiveness of a Mass Distribution of Long-Lasting Insecticidal Nets: A Modelling Study. Malaria Journal, 12, 77. 1475-2875-12-77 [pii]

[59] Labbe, P., Berthomieu, A., Berticat, C., Alout, H., Raymond, M., Lenormand, T. and Weill, M. (2007) Independent Duplications of the Acetylcholinesterase Gene Conferring Insecticide Resistance in the Mosquito Culex pipiens. Molecular Biology and Evolution, 24, 1056-1067. msm025 [pii] 
[60] Liu, Y., Zhang, H., Qiao, C., Lu, X. and Cui, F. (2011) Correlation between Carboxylesterase Alleles and Insecticide Resistance in Culex pipiens Complex from China. Parasites \& Vectors, 4, 236. 1756-3305-4-236 [pii]

[61] Osta, M.A., Rizk, Z.J., Labbe, P., Weill, M. and Knio, K. (2012) Insecticide Resistance to Organophosphates in Culex pipiens Complex from Lebanon. Parasites \& Vectors, 5, 132. 1756-3305-5-132 [pii]

[62] Djegbe, I., Cornelie, S., Rossignol, M., Demettre, E., Seveno, M., Remoue, F. and Corbel, V. (2011) Differential Expression of Salivary Proteins between Susceptible and Insecticide-Resistant Mosquitoes of Culex quinquefasciatus. PLoS ONE, 6, Article ID: e17496. http://dx.doi.org/10.1371/journal.pone.0017496

[63] Park, H.W., Bideshi, D.K., Wirth, M.C., Johnson, J.J., Walton, W.E. and Federici, B.A. (2005) Recombinant Larvicidal Bacteria with Markedly Improved Efficacy against Culex Vectors of West Nile Virus. American Journal of Tropical Medicine and Hygiene, 72, 732-738. 72/6/732 [pii]

[64] Becnel, J.J. (2006) Prospects for the Mosquito Baculovirus CuniNPV as a Tool for Mosquito Control. Journal of the American Mosquito Control Association, 22, 523-526. http://dx.doi.org/10.2987/8756-971X(2006)22[523:PFTMBC]2.0.CO;2

[65] McGraw, E.A. and O’Neill, S.L. (2013) Beyond Insecticides: New Thinking on an Ancient Problem. Nature Reviews Microbiology, 11, 181-193. nrmicro2968 [pii]

[66] Hoffmann, A.A., Montgomery, B.L., Popovici, J., Iturbe-Ormaetxe, I., Johnson, P.H., Muzzi, F., Greenfield, M., Durkan, M., Leong, Y.S., Dong, Y., Cook, H., Axford, J., Callahan, A.G., Kenny, N., Omodei, C., McGraw, E.A., Ryan, P.A., Ritchie, S.A., Turelli, M. and O’Neill, S.L. (2011) Successful Establishment of Wolbachia in Aedes Populations to Suppress Dengue Transmission. Nature, 476, 454-457. nature10356 [pii]

[67] McMeniman, C.J., Lane, R.V., Cass, B.N., Fong, A.W., Sidhu, M., Wang, Y.F. and O’Neill, S.L. (2009) Stable Introduction of a Life-Shortening Wolbachia Infection into the Mosquito Aedes aegypti. Science, 323, 141-144. 323/5910/141 [pii]

[68] Glaser, R.L. and Meola, M.A. (2010) The Native Wolbachia Endosymbionts of Drosophila melanogaster and Culex quinquefasciatus Increase Host Resistance to West Nile Virus Infection. PLoS ONE, 5, Article ID: e11977.

[69] Dodson, B.L., Kramer, L.D. and Rasgon, J.L. (2011) Larval Nutritional Stress Does Not Affect Vector Competence for West Nile Virus (WNV) in Culex tarsalis. Vector-Borne and Zoonotic Diseases, 11, 1493-1497. http://dx.doi.org/10.1089/vbz.2011.0662

[70] Michaelakis, A., Strongilos, A.T., Bouzas, E.A., Koliopoulos, G. and Couladouros, E.A. (2009) Larvicidal Activity of Naturally Occurring Naphthoquinones and Derivatives against the West Nile Virus Vector Culex pipiens. Parasitology Research, 104, 657-662. http://dx.doi.org/10.1007/s00436-008-1242-7

[71] LaBeaud, A.D., Bashir, F. and King, C.H. (2011) Measuring the Burden of Arboviral Diseases: The Spectrum of Morbidity and Mortality from Four Prevalent Infections. Population Health Metrics, 9, 1. 1478-7954-9-1 [pii]

[72] Kilpatrick, A.M., Kramer, L.D., Campbell, S.R., Alleyne, E.O., Dobson, A.P. and Daszak, P. (2005) West Nile Virus Risk Assessment and the Bridge Vector Paradigm. Emerging Infectious Diseases, 11, 425-429. http://dx.doi.org/10.3201/eid1103.040364

[73] Fontaine, A., Diouf, I., Bakkali, N., Misse, D., Pages, F., Fusai, T., Rogier, C. and Almeras, L. (2011) Implication of Haematophagous Arthropod Salivary Proteins in Host-Vector Interactions. Parasites \& Vectors, 4, 187. 1756-3305-4-187 [pii]

[74] Ribeiro, J.M. and Francischetti, I.M. (2003) Role of Arthropod Saliva in Blood Feeding: Sialome and Post-Sialome Perspectives. Annual Review of Entomology, 48, 73-88. 060402.102812 [pii]

[75] Ribeiro, J.M. (1989) Vector Saliva and Its Role in Parasite Transmission. Experimental Parasitology, 69, $104-106$. http://dx.doi.org/10.1016/0014-4894(89)90177-X

[76] Andrade, B.B., Teixeira, C.R., Barral, A. and Barral-Netto, M. (2005) Haematophagous Arthropod Saliva and Host Defense System: A Tale of Tear and Blood. Anais da Academia Brasileira de Ciências, 77, 665-693. S0001-37652005000400008 [pii]

[77] Francischetti, I.M., Sa-Nunes, A., Mans, B.J., Santos, I.M. and Ribeiro, J.M. (2009) The Role of Saliva in Tick Feeding. Frontiers in Bioscience, 14, 2051-2088. 3363 [pii]

[78] Titus, R.G., Bishop, J.V. and Mejia, J.S. (2006) The Immunomodulatory Factors of Arthropod Saliva and the Potential for These Factors to Serve as Vaccine Targets to Prevent Pathogen Transmission. Parasite Immunology, 28, 131-141. pim807 [pii]

[79] Orlandi-Pradines, E., Almeras, L., Denis de, S.L., Barbe, S., Remoue, F., Villard, C., Cornelie, S., Penhoat, K., Pascual, A., Bourgouin, C., Fontenille, D., Bonnet, J., Corre-Catelin, N., Reiter, P., Pages, F., Laffite, D., Boulanger, D., Simondon, F., Pradines, B., Fusai, T. and Rogier, C. (2007) Antibody Response against Saliva Antigens of Anopheles gambiae and Aedes aegypti in Travellers in Tropical Africa. Microbes and Infection, 9, 1454-1462. S1286-4579(07)00269-9 [pii] 
[80] Remoue, F., Cisse, B., Ba, F., Sokhna, C., Herve, J.P., Boulanger, D. and Simondon, F. (2006) Evaluation of the Antibody Response to Anopheles Salivary Antigens as a Potential Marker of Risk of Malaria. Transactions of the Royal Society of Tropical Medicine and Hygiene, 100, 363-370. S0035-9203(05)00288-9 [pii]

[81] Das, M.K., Mishra, A., Beuria, M.K. and Dash, A.P. (1991) Human Natural Antibodies to Culex quinquefasciatus: Age-Dependent Occurrence. Journal of the American Mosquito Control Association, 7, 319-321.

[82] Malafronte, R.S., Calvo, E., James, A.A. and Marinotti, O. (2003) The Major Salivary Gland Antigens of Culex quinquefasciatus Are D7-Related Proteins. Insect Biochemistry and Molecular Biology, 33, 63-71.

[83] Wanasen, N., Nussenzveig, R.H., Champagne, D.E., Soong, L. and Higgs, S. (2004) Differential Modulation of Murine Host Immune Response by Salivary Gland Extracts from the Mosquitoes Aedes aegypti and Culex quinquefasciatus. Medical and Veterinary Entomology, 18, 191-199. MVE498 [pii]

[84] Wongkamchai, S., Khongtak, P., Leemingsawat, S., Komalamisra, N., Junsong, N., Kulthanan, K., Wisuthsarewong, W. and Boitano, J.J. (2010) Comparative Identification of Protein Profiles and Major Allergens of Saliva, Salivary Gland and Whole Body Extracts of Mosquito Species in Thailand. Asian Pacific Journal of Allergy and Immunology, 28, 162-169.

[85] Asada, H., Saito-Katsuragi, M., Niizeki, H., Yoshioka, A., Suguri, S., Isonokami, M., Aoki, T., Ishihara, S., Tokura, Y., Iwatsuki, K. and Miyagawa, S. (2005) Mosquito Salivary Gland Extracts Induce EBV-Infected NK Cell Oncogenesis via CD4 T Cells in Patients with Hypersensitivity to Mosquito Bites. Journal of Investigative Dermatology, 125, 956961. JID23915 [pii]

[86] Asada H. (2007) Hypersensitivity to Mosquito Bites: A Unique Pathogenic Mechanism Linking Epstein-Barr Virus Infection, Allergy and Oncogenesis. Journal of Dermatological Science, 45, 153-160.

[87] Ramakrishnan, C., Rademacher, A., Soichot, J., Costa, G., Waters, A.P., Janse, C.J., Ramesar, J., Franke-Fayard, B.M. and Levashina, E.A. (2012) Salivary Gland-Specific P. berghei Reporter LINES Enable Rapid Evaluation of Tissue-Specific Sporozoite Loads in Mosquitoes, PLoS One, 7, Article ID: e36376.

[88] Fontaine, A., Fusai, T., Briolant, S., Buffet, S., Villard, C., Baudelet, E., Pophillat, M., Granjeaud, S., Rogier, C. and Almeras, L. (2012) Anopheles Salivary Gland Proteomes from Major Malaria Vectors. BMC Genomics, $13,614$. 1471-2164-13-614 [pii]

[89] Ali, Z.M., Bakli, M., Fontaine, A., Bakkali, N., Hai, V.V., Audebert, S., Boublik, Y., Pages, F., Remoue, F., Rogier, C., Fraisier, C. and Almeras, L. (2012) Assessment of Anopheles Salivary Antigens as Individual Exposure Biomarkers to Species-Specific Malaria Vector Bites. Malaria Journal, 11, 439. 1475-2875-11-439 [pii]

[90] Sagna, A.B., Sarr, J.B., Gaayeb, L., Drame, P.M., Ndiath, M.O., Senghor, S., Sow, C.S., Poinsignon, A., Seck, M., Hermann, E., Schacht, A.M., Faye, N., Sokhna, C., Remoue, F. and Riveau, G. (2013) gSG6-P1 Salivary Biomarker Discriminates Micro-Geographical Heterogeneity of Human Exposure to Anopheles Bites in Low and Seasonal Malaria Areas. Parasites \& Vectors, 6, 68. 1756-3305-6-68 [pii]

[91] Drame, P.M., Machault, V., Diallo, A., Cornelie, S., Poinsignon, A., Lalou, R., Sembene, M., Dos, S.S., Rogier, C., Pages, F., Le Hesran, J.Y. and Remoue, F. (2012) IgG Responses to the gSG6-P1 Salivary Peptide for Evaluating Human Exposure to Anopheles Bites in Urban Areas of Dakar Region, Senegal. Malaria Journal, 11, 72. 1475-2875-11-72 [pii]

[92] Rizzo, C., Ronca, R., Fiorentino, G., Verra, F., Mangano, V., Poinsignon, A., Sirima, S.B., Nebie, I., Lombardo, F., Remoue, F., Coluzzi, M., Petrarca, V., Modiano, D. and Arca, B. (2011) Humoral Response to the Anopheles gambiae Salivary Protein gSG6: A Serological Indicator of Exposure to Afrotropical Malaria Vectors. PLoS ONE, 6, Article ID: e17980. http://dx.doi.org/10.1371/journal.pone.0017980

[93] Drame, P.M., Poinsignon, A., Besnard, P., Cornelie, S., Le, M.J., Toto, J.C., Foumane, V., Dos-Santos, M.A., Sembene, M., Fortes, F., Simondon, F., Carnevale, P. and Remoue, F. (2010) Human Antibody Responses to the Anopheles Salivary gSG6-P1 Peptide: A Novel Tool for Evaluating the Efficacy of ITNs in Malaria Vector Control. PLoS ONE, 5, Article ID: e15596. http://dx.doi.org/10.1371/journal.pone.0015596

[94] Poinsignon, A., Samb, B., Doucoure, S., Drame, P.M., Sarr, J.B., Sow, C., Cornelie, S., Maiga, S., Thiam, C., Rogerie, F., Guindo, S., Hermann, E., Simondon, F., Dia, I., Riveau, G., Konate, L. and Remoue, F. (2010) First Attempt to Validate the gSG6-P1 Salivary Peptide as an Immuno-Epidemiological Tool for Evaluating Human Exposure to Anopheles Funestus Bites. Tropical Medicine \& International Health, 15, 1198-1203. TMI2611 [pii]

[95] Drame, P.M., Poinsignon, A., Besnard, P., Le, M.J., Dos-Santos, M.A., Sow, C.S., Cornelie, S., Foumane, V., Toto, J.C., Sembene, M., Boulanger, D., Simondon, F., Fortes, F., Carnevale, P. and Remoue, F. (2010) Human Antibody Response to Anopheles gambiae Saliva: An Immuno-Epidemiological Biomarker to Evaluate the Efficacy of Insecticide-Treated Nets in Malaria Vector Control. American Journal of Tropical Medicine and Hygiene, 83, 115-121. 83/1/115 [pii]

[96] Poinsignon, A., Cornelie, S., Ba, F., Boulanger, D., Sow, C., Rossignol, M., Sokhna, C., Cisse, B., Simondon, F. and Remoue, F. (2009) Human IgG Response to a Salivary Peptide, gSG6-P1, as a New Immuno-Epidemiological Tool for 
Evaluating Low-Level Exposure to Anopheles Bites. Malaria Journal, 8, 198. 1475-2875-8-198 [pii]

[97] Poinsignon, A., Cornelie, S., Mestres-Simon, M., Lanfrancotti, A., Rossignol, M., Boulanger, D., Cisse, B., Sokhna, C., Arca, B., Simondon, F. and Remoue, F. (2008) Novel Peptide Marker Corresponding to Salivary Protein gSG6 Potentially Identifies Exposure to Anopheles Bites. PLoS ONE, 3, Article ID: e2472. http://dx.doi.org/10.1371/journal.pone.0002472

[98] Arensburger, P., Megy, K., Waterhouse, R.M., Abrudan, J., Amedeo, P., Antelo, B., Bartholomay, L., Bidwell, S., Caler, E., Camara, F., Campbell, C.L., Campbell, K.S., Casola, C., Castro, M.T., Chandramouliswaran, I., Chapman, S.B., Christley, S., Costas, J., Eisenstadt, E., Feschotte, C., Fraser-Liggett, C., Guigo, R., Haas, B., Hammond, M., Hansson, B.S., Hemingway, J., Hill, S.R., Howarth, C., Ignell, R., Kennedy, R.C., Kodira, C.D., Lobo, N.F., Mao, C., Mayhew, G., Michel, K., Mori, A., Liu, N., Naveira, H., Nene, V., Nguyen, N., Pearson, M.D., Pritham, E.J., Puiu, D., Qi, Y., Ranson, H., Ribeiro, J.M., Roberston, H.M., Severson, D.W., Shumway, M., Stanke, M., Strausberg, R.L., Sun, C., Sutton, G., Tu, Z.J., Tubio, J.M., Unger, M.F., Vanlandingham, D.L., Vilella, A.J., White, O., White, J.R., Wondji, C.S., Wortman, J., Zdobnov, E.M., Birren, B., Christensen, B.M., Collins, F.H., Cornel, A., Dimopoulos, G., Hannick, L.I., Higgs, S., Lanzaro, G.C., Lawson, D., Lee, N.H., Muskavitch, M.A., Raikhel, A.S. and Atkinson, P.W. (2010) Sequencing of Culex quinquefasciatus Establishes a Platform for Mosquito Comparative Genomics. Science, 330, 8688. 330/6000/86 [pii]

[99] Ribeiro, J.M., Charlab, R., Pham, V.M., Garfield, M. and Valenzuela, J.G. (2004) An Insight into the Salivary Transcriptome and Proteome of the Adult Female Mosquito Culex pipiens Quinquefasciatus. Insect Biochemistry and Molecular Biology, 34, 543-563. S0965174804000323 [pii]

[100] Calvo, E., Sanchez-Vargas, I., Favreau, A.J., Barbian, K.D., Pham, V.M., Olson, K.E. and Ribeiro, J.M. (2010) An Insight into the Sialotranscriptome of the West Nile Mosquito Vector, Culex tarsalis. BMC Genomics, 11, 51. 1471-2164-11-51 [pii]

[101] Arca, B., Lombardo, F., Francischetti, I.M., Pham, V.M., Mestres-Simon, M., Andersen, J.F. and Ribeiro, J.M. (2007) An Insight into the Sialome of the Adult Female Mosquito Aedes albopictus. Insect Biochemistry and Molecular Biology, 37, 107-127. S0965-1748(06)00219-0 [pii]

[102] Ribeiro, J.M., Arca, B., Lombardo, F., Calvo, E., Phan, V.M., Chandra, P.K. and Wikel, S.K. (2007) An Annotated Catalogue of Salivary Gland Transcripts in the Adult Female Mosquito, Aedes aegypti. BMC Genomics, 8, 6. 1471-2164-8-6 [pii]

[103] Reagan, K.L. (2010) Identification of Culex tarsalis D7 Salivary Protein and Role of Salivary Protein Vaccine on Subsequent West Nile Virus Infection. Colorado State University Libraries, Fort Collins, 134 p.

[104] Ribeiro, J.M.C. and Arcà, B. (2009) From Sialomes to the Sialoverse: An Insight into the Salivary Potion of Blood Feeding Insects. Advances in Insect Physiology, 37, 59-118.

[105] Osorio, J.E., Godsey, M.S., Defoliart, G.R. and Yuill, T.M. (1996) La Crosse Viremias in White-Tailed Deer and Chipmunks Exposed by Injection or Mosquito Bite. American Journal of Tropical Medicine and Hygiene, 54, 338-342.

[106] Vaughan, J.A., Scheller, L.F., Wirtz, R.A. and Azad, A.F. (1999) Infectivity of Plasmodium Berghei Sporozoites Delivered by Intravenous Inoculation versus Mosquito Bite: Implications for Sporozoite Vaccine Trials. Infection and Immunity, 67, 4285-4289.

[107] Limesand, K.H., Higgs, S., Pearson, L.D. and Beaty, B.J. (2000) Potentiation of Vesicular Stomatitis New Jersey Virus Infection in Mice by Mosquito Saliva. Parasite Immunology, 22, 461-467.

[108] Gillan, V. and Devaney, E. (2004) Mosquito Transmission Modulates the Immune Response in Mice Infected with the L3 of Brugia pahangi. Parasite Immunology, 26, 359-363.

[109] Donovan, M.J., Messmore, A.S., Scrafford, D.A., Sacks, D.L., Kamhawi, S. and Ann McDowell, M. (2007) Uninfected Mosquito Bites Confer Protection against Infection with Malaria Parasites. Infection and Immunity, 75, 25232530.

[110] Styer, L.M., Lim, P.Y., Louie, K.L., Albright, R.G., Kramer, L.D. and Bernard, K.A. (2011) Mosquito Saliva Causes Enhancement of West Nile Virus Infection in Mice. Journal of Virology, 85, 1517-1527. JVI.01112-10 [pii]

[111] Schneider, B.S., McGee, C.E., Jordan, J.M., Stevenson, H.L., Soong, L. and Higgs, S. (2007) Prior Exposure to Uninfected Mosquitoes Enhances Mortality in Naturally-Transmitted West Nile Virus Infection. PLoS ONE, 2, Article ID: e1171. http://dx.doi.org/10.1371/journal.pone.0001171

[112] Schneider, B.S., Soong, L., Stevenson, H.L., McGee, C.E. and Higgs, S. (2010) Aedes aegypti Saliva Alters Leukocyte Recruitment and Cytokine Signaling by Antigen-Presenting Cells during West Nile Virus Infection. PLoS ONE, 5, Article ID: e11704.

[113] Styer, L.M., Bernard, K.A. and Kramer, L.D. (2006) Enhanced Early West Nile Virus Infection in Young Chickens Infected by Mosquito Bite: Effect of Viral Dose. American Journal of Tropical Medicine and Hygiene, 75, 337-345. 75/2/337 [pii] 
[114] Schneider, B.S., Soong, L., Girard, Y.A., Campbell, G., Mason, P. and Higgs, S. (2006) Potentiation of West Nile Encephalitis by Mosquito Feeding. Viral Immunology, 19, 74-82. http://dx.doi.org/10.1089/vim.2006.19.74

[115] Schneider, B.S. and Higgs, S. (2008) The Enhancement of Arbovirus Transmission and Disease by Mosquito Saliva Is Associated with Modulation of the Host Immune Response. Transactions of the Royal Society of Tropical Medicine and Hygiene, 102, 400-408. S0035-9203(08)00053-9 [pii]

[116] Diamond, M.S. (2009) West Nile Encephalitis Virus Infection: Viral Pathogenesis and the Host Immune Response. Springer Science \& Business Media, Berlin, 504 p.

[117] Mans, B.J. and Francischetti, I.M.B. (2011) Sialomic Perspectives on the Evolution of Blood-Feeding Behavior in Arthropods: Future Therapeutics by Natural Design. In: Toxins and Hemostasis, Springer Science + Business Media, New York, 21-44.

[118] Morris, R.V., Shoemaker, C.B., David, J.R., Lanzaro, G.C. and Titus, R.G. (2001) Sandfly Maxadilan Exacerbates Infection with Leishmania major and Vaccinating against It Protects against L. major Infection. Journal of Immunology, 167, 5226-5230. http://dx.doi.org/10.4049/jimmunol.167.9.5226

[119] Koo, Q.Y., Khan, A.M., Ramdas, S., Miotto, O., Wee Tan, T., Jung, K.O., Salmon, J. and August, J.T. (2009) Conservation and Variability of West Nile Virus Proteins. PLoS ONE, 4, Article ID: e5352.

[120] Colpitts, T.M., Conway, M.J., Montgomery, R.R. and Fikrig, E. (2012) West Nile Virus: Biology, Transmission, and Human Infection. Clinical Microbiology Reviews, 25, 635-648. 25/4/635 [pii]

[121] Gubler, D.J. (2002) The Global Emergence/Resurgence of Arboviral Diseases as Public Health Problems. Archives of Medical Research, 33, 330-342. S0188-4409(02)00378-8 [pii]

[122] Shi, P.Y. and Wong, S.J. (2003) Serologic Diagnosis of West Nile Virus Infection. Expert Review of Molecular Diagnostics, 3, 733-741. ERM030606 [pii]

[123] Rossi, S.L., Ross, T.M. and Evans, J.D. (2010) West Nile Virus. Clinics in Laboratory Medicine, 30, 47-65.

[124] Kalil, A.C., Devetten, M.P., Singh, S., Lesiak, B., Poage, D.P., Bargenquast, K., Fayad, P. and Freifeld, A.G. (2005) Use of Interferon-Alpha in Patients with West Nile Encephalitis: Report of 2 Cases. Clinical Infectious Diseases, 40, 764-766.

[125] Lewis, M. and Amsden, J.R. (2007) Successful Treatment of West Nile Virus Infection after Approximately 3 Weeks into the Disease Course. Pharmacotherapy, 27, 455-458.

[126] Loginova, S.I., Borisevich, S.V., Pashchenko, Iu.A. and Bondarev, V.P. (2009) Ribavirin Prophylaxis and Therapy of Experimental West Nile Fever. Antibiotiki i Khimioterapiia, 54, 17-20.

[127] Shimoni, Z., Niven, M.J., Pitlick, S. and Bulvik, S. (2001) Treatment of West Nile Virus Encephalitis with Intravenous Immunoglobulin. Emerging Infectious Diseases, 7.

[128] Petersen, L.R. (2008) Clinical Manifestations, Diagnosis, and Treatment of West Nile Virus Infection. In: Rose, B., Ed., UpToDate. UpToDate, Waltham.

[129] Dhingra, V., Li, Q., Allison, A.B., Stallknecht, D.E. and Fu, Z.F. (2005) Proteomic Profiling and Neurodegeneration in West-Nile-Virus-Infected Neurons. Journal of Biomedicine \& Biotechnology, 2005, 271-279.

[130] Fredericksen, B.L., Smith, M., Katze, M.G., Shi, P.Y. and Gale Jr., M. (2004) The Host Response to West Nile Virus Infection Limits Viral Spread through the Activation of the Interferon Regulatory Factor 3 Pathway. Journal of Virology, 78, 7743-7747.

[131] Loeb, M., Eskandarian, S., Rupp, M., Fishman, N., Gasink, L., Patterson, J., Bramson, J., Hudson, T.J. and Lemire, M. (2011) Genetic Variants and Susceptibility to Neurological Complications Following West Nile Virus Infection. Journal of Infectious Diseases, 204, 1031-1037.

[132] Pastorino, B., Boucomont-Chapeaublanc, E., Peyrefitte, C.N., Belghazi, M., Fusaï, T., Rogier, C., Tolou, H.J. and Almeras, L. (2009) Identification of Cellular Proteome Modifications in Response to West Nile Virus Infection. Molecular \& Cellular Proteomics, 8, 1623-1637.

[133] Venter, M., Myers, T.G., Wilson, M.A., Kindt, T.J., Paweska, J.T., Burt, F.J., Leman, P.A. and Swanepoel, R. (2005) Gene Expression in Mice Infected with West Nile Virus Strains of Different Neurovirulence. Virology, 342, 119-140.

[134] Fraisier, C., Camoin, L., Lim, S., Bakli, M., Belghazi, M., Fourquet, P., Granjeaud, S., Osterhaus, A.D., Koraka, P., Martina, B. and Almeras, L. (2013) Altered Protein Networks and Cellular Pathways in Severe West Nile Disease in Mice. PLoS ONE, 8, Article ID: e68318;;PONE-D-13-10430 [pii]

[135] Dafna Bonneh-Barkay (2011) Biomarkers of Encephalitis. In: Hayasaka, D., Ed., InTech. http://www.intechopen.com/books/pathogenesis-of-encephalitis/biomarkers-of-encephalitis

[136] Grahn, A., Hagberg, L., Nilsson, S., Blennow, K., Zetterberg, H. and Studahl, M. (2013) Cerebrospinal Fluid Biomarkers in Patients with Varicella-Zoster Virus CNS Infections. Journal of Neurology, 260, 1813-1821. 
http://dx.doi.org/10.1007/s00415-013-6883-5

[137] Petzold, A., Groves, M., Leis, A.A., Scaravilli, F. and Stokic, D.S. (2010) Neuronal and Glial Cerebrospinal Fluid Protein Biomarkers Are Elevated after West Nile Virus Infection. Muscle \& Nerve, 41, 42-49. http://dx.doi.org/10.1002/mus.21448

[138] Petzold, A., Keir, G., Green, A.J., Giovannoni, G. and Thompson, E.J. (2004) An ELISA for Glial Fibrillary Acidic Protein. Journal of Immunological Methods, 287, 169-177.

[139] Petzold, A., Keir, G., Green, A.J., Giovannoni, G. and Thompson, E.J. (2003) A Specific ELISA for Measuring Neurofilament Heavy Chain Phosphoforms. Journal of Immunological Methods, 278, 179-190.

[140] Petzold, A., Green, A.J., Keir, G., Fairley, S., Kitchen, N., Smith, M. and Thompson, E.J. (2002) Role of Serum S100B as an Early Predictor of High Intracranial Pressure and Mortality in Brain injury: A Pilot Study. Critical Care Medicine, 30, 2705-2710.

[141] Shichita, T., Ago, T., Kamouchi, M., Kitazono, T., Yoshimura, A. and Ooboshi, H. (2012) Novel Therapeutic Strategies Targeting Innate Immune Responses and Early Inflammation after Stroke. Journal of Neurochemistry, 123, 29-38.

[142] Allonso, D., Vázquez, S., Guzmán, M.G. and Mohana-Borges, R. (2013) High Mobility Group Box 1 Protein as an Auxiliary Biomarker for Dengue Diagnosis. American Journal of Tropical Medicine and Hygiene, 88, 506-509.

[143] Shichita, T., Hasegawa, E., Kimura, A., Morita, R., Sakaguchi, R., Takada, I., et al. (2012) Peroxiredoxin Family Proteins Are Key Initiators of Post-Ischemic Inflammation in the Brain. Nature Medicine, 18, 911-917.

[144] Zhang, J., Takahashi, H.K., Liu, K., Wake, H., Liu, R., Maruo, T., Date, I., Yoshino, T., Ohtsuka, A., Mori, S. and Nishibori, M. (2011) Anti-High Mobility Group Box-1 Monoclonal Antibody Protects the Blood-Brain Barrier from Ischemia-Induced Disruption in Rats. Stroke, 42, 1420-1428.

[145] Hemingway, J., Field, L. and Vontas, J. (2002) An Overview of Insecticide Resistance. Science, 298, 96-97. 298/5591/96 [pii]

[146] Liu, N., Xu, Q., Li, T., He, L. and Zhang, L. (2009) Permethrin Resistance and Target Site Insensitivity in the Mosquito Culex quinquefasciatus in Alabama. Journal of Medical Entomology, 46, 1424-1429. http://dx.doi.org/10.1603/033.046.0625

[147] Federici, B.A., Park, H.W., Bideshi, D.K., Wirth, M.C. and Johnson, J.J. (2003) Recombinant Bacteria for Mosquito Control. Journal of Experimental Biology, 206, 3877-3885. http://dx.doi.org/10.1242/jeb.00643

[148] Alphey, L. (2009) Natural and Engineered Mosquito Immunity. Journal of Biology, 8, 40. jbiol143 [pii]

[149] Deredec, A., Burt, A. and Godfray, H.C. (2008) The Population Genetics of Using Homing Endonuclease Genes in Vector and Pest Management. Genetics, 179, 2013-2026. genetics.108.089037 [pii]

[150] Franz, A.W., Sanchez-Vargas, I., Piper, J., Smith, M.R., Khoo, C.C., James, A.A. and Olson, K.E. (2009) Stability and Loss of a Virus Resistance Phenotype over Time in Transgenic Mosquitoes Harbouring an Antiviral Effector Gene. Insect Molecular Biology, 18, 661-672. IMB908 [pii]

[151] Bai, F., Wang, T., Pal, U., Bao, F., Gould, L.H. and Fikrig, E. (2005) Use of RNA Interference to Prevent Lethal Murine West Nile Virus Infection. Journal of Infectious Diseases, 191, 1148-1154. JID33669 [pii] 